\title{
TERORISME DALAM DISKURSUS HUBUNGAN ISLAM DAN BARAT
}

\author{
Oleb: Dadan Muttaqien*
}

\section{Abstract}

Terrorism issue has been built base on politic and economy motive which were covered by religion motive. After spreading terrorism issue, the international society accused that Islam is religion which support terrorism, so that Islam must responsible to the terrorism action that bas been spreading in this era. As known, the impact of. terrorism issue obstructs relations between Islam and the west. One of the efforts which is possible to overcome this problem is inter-religions and inter-civilizations dialogue, in spite of west hegemony, especially United State implanted to every aspect of life and their political interests more dominant than their desire to create peace in this world. The other possible way is participation of education and culture.

ومن المعلوم، أن الإرهايية مبنية على أمور السياسة-والإقتصاية التي يلتبسه الذدين. فبعد أن انتشرت

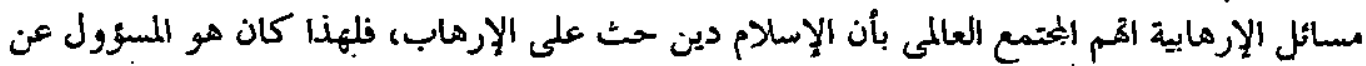

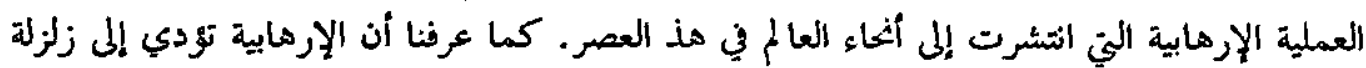
العلاقة بين الإسلام والغرب. فالاقتراح الذي بمكن استفاده لعلاج العملية الإرهاية هو ألمناقئة والحوار بين الحضضارات والأديان، مهما كانت سيطرة الغربية على كل شؤون الحلياة السياسية. والطريق المناسب لعلاج هذه المسئلة هي دور التريية والثقافة، مثل تعليم التسامتخ، والعدالة، والصلح وغير ذلك من القيم المحمودة.

Keywords: terorisme, diskursus, bubungan, Islam dan Barat

* Dosen Tetap FakuItas Ilmu Agama Islam Universitas Islam Indonesia Yogyakatta 


\section{A. Pendabuluan}

Penyerangan gedung WTC Amerika Serikat, pengeboman hotel JW Marriot, dan peledakan beberapa tempat umum lainnya, menjadikan terotisme mendapat perhatian serius dari semua kalangan masyarakat. Terorisme merupakan bentuk kekerasan (violence) yakni suatu sifat atau keadaan yang mengandung kekuatan, tekanan dan paksaan, yang berarti tekanan yang keras, suatu dimensi kekerasan yang bukan saja fisik tetapi juga psikologis dengan maksud menciptakan bentuk teror terhadap orang-orang tertentu atau kepada kelompok orang dan dapat juga kepada mesyarakat umum.

Tetorisme berkembang seiring dengan perkembangan zaman telah menjadi bagian dan ciri pergetakan politik dari suatu kelompok, yang mengakibatkan terjadinya kerusuhan, nyala api yang besar, maupun lumuran darah dati otang-orang yang tidak bersalah

\section{B. Pengertian dan Motif Terorisme}

Terorisme dapat dilihat dari beberapa sudut ilmu yaitu sosiologi, kriminologi, politik, psikiatri, hubungan internasional dan hukum. Oleh karena itu, sulit untuk mendapatkan suatu rumusan defenisi yang mampu mencakup seluruh aspek dan berbagai dimensi disiplin ilmu tersebut. Menurut Konvensi PBB tahun 1937, terorisme adalah segala bentuk tindak kejahatan yang ditujukan langsung kepada negara dengan maksud menciptakan bentuk teror terhadap orang-orang tertentu atau kepada kelompok orang dan dapat juga kepada mesyarakat umum. US Department of Defense tahun 1990 mendefenisikan sebagai perbuatan melawan hukum atau tindakan yang mengandung ancaman dengan kekerasan atau paksaan terhadap individu atau hak milik untuk memaksa/mengintimidasi pemerintah atau masyarakat dengan tujuan politik, agama, dan idiologi. Sementara dalam Ensiklopedi Oxford, terorisme merupakan penggunaan kekerasan untuk tujuan secara sengaja dan acak terhadap kelompok yang dilindungi. Defenisi ini lebih bersifat fungsional dan tidak mengundang polemik, bersifat tingkas dan universal. Sedangkan untuk mengetahui pelakunya bisa negara, atau perorangan yang bertindak sendiri."

Sejarah terorisme moderen, terorisme muncul pada abad 19 dan menjelang terjadinya Perang Dunia I yang terjadi hampir di setiap negara. Catatan sejarah membuktikan bahwa pada tahun 1980-an aksi terorisme Armenia melawan pemerintah Turki, yang berakhir dengan bencana pembunuhan massal terhadap warga Armenia pada Petang Dunia I. Dekade Perang Dunia I tersebut terorisme dtidentikkan sebagai bagian dari gerakan sayap kiri yang berbasiskan idiologi.

Ciri-ciri terorisme șecara umum, mereka adalah organisasi yang baik, berdisiplin

${ }^{1}$ Loudewijk F. Paulus (2000), Terorisme, Buletin Balitbang Dephan. http.www.dephan.go.id. 
tinggi dan militan, mempunyai tujuan politik yang untuk mencapai tujuan tersebut dilakukan dengan perbuatan kriminal. Sehingga tidak pernah mengindahkan normanorma yang berlaku seperti agama, hukum, sosial dan sebagainya. Ciri lain adalah sasaran tembak mereka harus dapat dipastikan mempunyai dampak psikologis yang tinggi sehingga menimbulkan rasa takut dan mendapatkan publikasi internasional, sehingga organisasi mereka diketahui banyak orang secara luas. ${ }^{2}$

Motif terorisme terdiri dari; rasional, psikologi dan budaya yang meluas menjadi membebaskan tanah air, seperti perjuangan Palestina pada tanggal 15 Nopember 1988 yang memproklamasikan kemerdekaannya di Aljazair. Dapat juga motifnya dalam bentuk memisahkan diri dari pemerintahan yang sah (separatis), atau sebagai protes terhadap sistem sosial yang betlaku dan menyingkirkan musuh-musuh politik.

\section{Bentuk-Bentuk Terorisme}

Terorisme telah lahir sejak tibuan tahun silam, dengan dilakukannya psychological warfare pada zaman Yunani Kuno oleh Xenophon (430-349 SM), sebagai usaha untuk memperlemah lawan. Terorisme berkembang seiring dengan perkembangan zaman telah menjadi bagian dan ciri pergerakan politik dari suatu kelompok, yang mengakibatkan terjadinya kerusuhan, nyala api yang besar, maupun lumuran darah dari orang-orang yang tidak bersalah ${ }^{3}$

Pada saat ini terotisme dapat diattikulasikan dalam tiga bentuk. Pertama, terorisme yang betsifat personal. Aksi-aksi terorisme dilakukan oleh perorangan, biasanya dalam bentuk pengeboman bus seperti di Kairo, pengeboman mal-mạ dan pusat perbelanjaan juga dapat dikategorikan sebagai terorisme yang dilakukan secara personal. Kedua, terorisme yang bersifat kolektif. Para teroris biasariya melakukan aksinya secara terencana yang dilembagakan dalam sebuah jaringan yang rapi. Terotisme dalam kategori ini lebih dikenal seperti Jaringan Al-Qaeda pimpinan Usamah bin Laden dan yang menjadi sasaran dalam kategori terisme ini adalah simbolsimbol kekuasaan dan pusat-pusat perekonomian. Ketiga, terorisme yang dilakukan oleh negara (state terorism). Perdana Menteri malaysia Mahathir Muhammad sebagai penggagas pemikiran ini yang menurutnya terorisme yang dilakukan oleh negara tidak kalah dahsyatnya dari terorisme personal maupun kolektif. Bentuk terorisme kedua dapat dilakukan secara sembunyi-sembunyi sedangkan terorisme negara dapat dilakukan secara terang-terangan.

Terorisme negara tergantung pada konteks sesungguhnya, yang dapat mencakup tindakan kekerasan atau penindasan yang dilakukan oleh suatu pemerintahan atau negara proksi. Terorisme negara dapat ditujukan kepada penduduk negara yang bersangkutan, atau terhadap penduduk negara lainnya.

${ }^{2}$ Ibid.

${ }^{3}$ Adjie. S (2005), Aksi Terorisme Dunia, Jakarta: Pustaka Sinar Harapan, pp. 3-7. 
Tindakan tersebut dapat pula dilakukan oleh angkatan bersenjata negata itu sendiri seperti angkatan darat, polisi, atau organisasi lainnya yang dalam hal ini disebut terorisme yang disponsori oleh negara. Berbeda halnya jika tindak kekerasan yang dilakukan agen-agen pemerintah yang tidak secara khusus ditetapkan dalam kebijakan pemerintah. Sehingga pembunuhan yang dilakukann seorang polisi, misalnya tidak dianggap sebagai terorisme negara kecuali jika pemerintah mendukung tindakan itu.

Ketiga bentuk terorisme itu mempunyai titik temu, yaitu sama-sama mencari tumbal dan korban karena yang mencolok dalam terorisme adalah "balas dendam". Karenanya, terotisme identik dengan kenekatan dan keterpanggilan untuk melawan secara serampangan. Sebab tetoris biasanya melandaskan pada kebutuhan untuk membangun identitas tunggal yang mengandaikan adanya absolutisme baik dalam tataran suprastruktur maupun struktur. Gerakan terorisme dapat saja menggandeng agama, politik dan ekonomi. Apapun yang digandeng terorisme, sejatinya terorisme tetap menunjukkan wataknya yang serba hegemonik, anarkis dan radikal yang dicap semua tindakannya adalah buruk dan tidak manusiawi.

\section{Media Terorisme}

John L. Esposito, dkk menguak situasi hubungan Islam dan Barat yang akhirakhir ini kembali memanas. Akibat pencitraan Batat atas Islam melalui media massa dengan berbagai modusnya. Pencitraan Barat atas Islam di media massa Barat. MisaInya, adalah: seperti krisis Suez (1955-1956), Perang Arab-Istael (1967), krisis minyak (1973-1974), Revolusi Iran (1978-1979), kasus Salman Rushdie (1989), krisis Aljazair (1990-an), Perang Teluk (1991), dan pemburuan teroris Osamah bin Laden di Afghanistan (2002) Invasi AS ke Irak (2003). Menurut Nana Suryana, merah (baca: komunis) tidak lagi jadi ancaman, namun gantinya adalah 'ancaman hijau' (baca: Islam). Tidak peduli lagi apa makna Islam bagi para penganutnya, baik di Barat maupun di luar Barat, citra muslim sebagai teroris, fundamentalis, fanatik, rupanya cukup meyakinkan guna menghadirkan musuh yang sempat menghilang dalam sejarah kontemporer Barat. Bahkan lebih lanjut, Samuel P. Huntington dalam magnum opus-nya, dengan tegas menyebut, bahwa Islam akan menjadi musuh baru setelah tuntuhnya Uni Soviet dalam perang dingin.

Bila dilacak, salah satu alasan mengapa kaum muslim selalu menjadi sasaran distorsi Barat adalah, bahwa Islam dianggap sebagai agama kekerasan dan peradaban yang mengancam dominasi intelektual dan politik Barat. Bahkan, sebagaimana ditegarai oleh Watt, misalnya, ditegaskan bahwa persepsi historis Barat tentang IsIam ada dalam empat hal: (1) Islam adalah agama palsu dan terang-terangan menyimpang dari kebenaran; (2) Islam adalah agama yang tersebar melalui pedang; (3) Islam adalah agama pemanjaan diri; dan (4) Muhammad adalah musuh Kristus. 
Sejak kedatangannya, Islam dipandang oleh Barat sebagai problematis, terutama bagi 'teodesi' Kristen, dan menjadi trauma bagi Etopa. Sehingga tumbuhnya kembali gejala islamophobia tidak bisa dipersalahkan. Oleh katena itu, perlu ada semacam dialog dan sikap saling memahami (mutzal understanding). ${ }^{4}$

Kolonialisme adalah beban sejarah yang melekat dalam hubungan Islam-Barat. Pengalaman dijajah dan diperintah oleh Barat menjadi kendala yang tidak mudah disingkirkan, masyarakat Timur memiliki trauma. Hubungan keduanya mengalami gangguan, terutama dalam upaya menumbuhkan rasa dan sikap saling percaya. Tidak mudah untuk menjembuhkan luka akibat penjajahan tersebut.

Fase "pertengahan" Barat melahirkan "Petang Salib" (11-13 M), menurut Hasan Hanafi fase tersebut dapat dikategorikan sebagai bentuk kolonialisme pertama. ${ }^{5}$ Dalam invasinya, Barat menggunakan agama untuk melegitimasi tindakannya. Sedangkan bentuk kolonialisme modern terjadi sejak permulaan abad ke-18 hingga awal abad ke-20. Dalam kaitannya dengan hal ini, Samuel P Huntington mengatakan bahwa perbedaan peradaban bukan hanya suatu kenyataan, melainkan juga mendasar, yang telah menimbulkan konflik paling keras, betkepanjangan dan memakan korban yang tidak sedikit. Sepanjang abad ke-18 hingga 19, Barat menginvasi negara-negara Islam di Timur Tengah. Tujuannya adalah sumber daya alam dan membuka pasar baru, namun di samping itu juga dilatarbelakangi oleh identitas peradaban yang berbeda. ${ }^{6}$ Menurut Huntington peradaban terdiferensiasi oleh sejarah, bahasa, budaya, tradisi, dan yang lebih penting lagi, agama. Beban sejarah ekspansi Timur (baca: Islam ) ke wilayah Barat, sejak awal telah menyisakan dendam, sehingga menimbulkan semacam "serum" anti Timur. Maka dalam memahami kolonialisme Barat atas Timur tidak terlepas dari akar sejarah masa lalu tersebut, di mana Barat sebagai pihak yang kalah. Penguatan identitas dan semangat untuk mengalahkan Timur dimotivasi oleh beban masa lalu itu.

\section{E. Dialog antar Peradaban antar Agama sebagai Alternative Penyelesaian Aksi Terorisme}

Peradaban Islam dan Batat yang kita pahami, tidak terlepas dari kontestasi pemaknaan. Sungguhpun keduanya merupakan realitas objektif yang tak terbantahkan, namun makna yang dikandungnya mengalami "pergumulan". Sebab, makna dibangun dan dikontrol oleh kekuatan-kekuatan tertentu. Kekuatan-kekuatan tersebut berkontestasi "pendaulatan" dirinya menjadi pemilik otoritas untuk menafsirkan, memaknai dan mendefinisikan. Dengan demikian makna Barat dan

${ }^{4}$ Edwar Said (1978), Orientalism, ttp: Penguin, p. 55.

${ }^{5}$ Hasan Hanafi (2003), Cakrawala Baru Peradaban Global: Revolusi Islam wntuk Globalisme, Pluralisme, dan Egaliterisme antar Peradaban, Yogyakatta: IRCiSOD; p. 95.

"Samuel P. Huntington (1998), The Clash of Cinilizations and the Remaking of IVorld Order, London: Touchstone, p. 21. 
Islam terkait dengan kepentingan yang "betoperasi" di baliknya. Dalam perspektif teori analisis diskursus, sebuah institusi, praktik, dan konsep terkait dengan empat hal, yaitu keinginan, kekuasaan, disiplin, dan pemerintahan. Oleh Michael Foucault, keempat hal ini disebut formasi diskursif, bangunan yang mendasari sebuah diskursus ${ }^{7}$ dan pengetahuan, menurut Foucault, dikontrol oleh kekuatan-kekuatan dominan.

Pengetahuan tentang Islam ataupun Barat tidak bisa serta merta diyakini sebagai kebenaran. Islam yang dikonotasikan dengan terorisme, irasional, tidak menghormati kebebasan berpendapat, dan diskriminatif terhadap perempuan umpamanya, tidak bisa dibenarkan secara keseluruhan. Begitupula Barat yang dipersepsikan sebagai kolonialis dan imperialis. Sernua, merupakan definisi yang dibangun dan dikontrol oleh kelompok tertentu. Sedemikian rupa, sehingga makna Barat dan Islam begitu kuat melekat menjadi semacam stereotype bagi keduanya.

Kontestasi pemaknaan didorong oleh kepentingan mengkonstruksi identitas. Perlombaan tersebut melibatkan benturan kelompok yang betkepentingan. Diskursus tragedi WTC dan terorisme yang hangat beberapa waktu lalu, memptoduksi "ruang tanpa identitas". Tidak ada yang mengaku sebagai pelaku dari peristiwa itu, sehingga menciptakan "ruang", dimana setiap orang bisa "mengisinya". Posisi yang paling diuntungkan adalah kekuatan dominan yang menguasai media pembentuk opini. Olehnya, tragedi WTC dan teroris dialamatkan kepada kaum muslim, dan dunia internasional terhegemoni olehnya, sungguhpun kebenarannya tidak dapat dibuktikan hingga kini.

Dengan demikian, makna hanyalah sebuah produksi yang dikontestasikan, sehingga subjektifitas dan kepentingan bermain dalam konstruksi tersebut. Menafikan "formasi diskursif" yang berada di baliknya, akan memalingkan Islam dan Barat dari upaya saling memahami, menghormati, dan bekerjasama. Makna tidak muncul dengan sendirinya, melainkan diproduksi dan dikontrol, dikembangkan dan dibatasi. Ironisnya produksi tersebut tidak beroperasi secara tulus. Produksi makna berjalan dalam ajang kontestasi pemaknaan. Atas dasar itu, memahami makna dalam suatu wacana harus dikaitkan dengan formasi diskursif yang menggerakkannya.

Beberapa konferensi yang dilaksanakan di Indonesia, seperti; Jakarta International Islamic Conference (JIC) dan International Conference of Islamic Scholars (ICIS) berupaya untuk merekonstruksi makna Islam yang humanis dan toleran. Sebab selama ini, tindakan teror yang terjadi beberapa kali di dunia internasional dialamatkan kepada Islam. Bahkan Robert Spencer secara sarkastik menilai bahwa ajatan Islam mengandung nilai-nilai yang mendorong umatnya untuk melakukan kekerasan. ${ }^{8}$

${ }^{7}$ Michael Foulcault (1972), The Archatology of Kuowledge and the Discourse on Language, New Yotk: Pantheon Books, p. 41.

${ }^{8}$. Robert Spencer (2003), Islam Ditelanjangi: Pertanyaan-pertanyaan Subversif Seputar Doktrin dan Tradisi Kaum Muslim, Jakarta: Paramadina, pp. 9-11. 
Makna teroris yang dilekatkan kepada umat Islam telah mereduksinya. Padahal, sungguhpun kita membenarkan bahwa Amrozi dkk yang melakukan teror adalah bagian dari umat Islam, namun mereka tidak mewakili mainstream ajaran Islam. Tuduhan Spencer tetlampau menyederhanakan realitas objektif. Persoalan-persoalan semacam itu melatari upaya dialog antar-peradaban, Barat dan Islam.

Dialog antar-peradaban ingin mengurai kesalahpahaman yang terjadi. Olaf Schuman menilai, bahwa sejauh ini dominasi Barat adalah salah satu kendala besar'. Padahal dominasi salah-satu dari keduanya dalam mengkonstruksi makna akan menyulitkan kesaling-pahaman dan kerjasama. Meski harus diakui pula bahwa kekuatan peradaban Barat adalah dalam proyek epistemologinya, yaitu "aku berpikir maka aku ada". ${ }^{10}$ Sepatutnya, dialog antar-peradaban memposisikan Islam-Barat secara sejajar. Di satu sisi, peradaban Islam dan Barat memiliki cara pandang dan parameter yang berbeda, sementara di sisi lain keduanya dibebani harapan untuk mewujudkan tatanan global yang damai dan humanis.

\section{F. Dampak Isu Terorisme terbadap Hubungan Islam dan Barat}

Adnan M Wizan mencatat bahwa orientalisme muncul sebagai kelanjutan dari Perang Salib ${ }^{11}$ Lebih jelasnya Wizan mengatakan: Dalam sejarah, sumber permusuhan ini dikenal sebagai kelanjutan perang salib dan diduga sebagai faktor yang mendorong berdirinya gerakan orientalisme. Semua pasukan salib dapat dihancurkan oleh kekuatan Islam dan tentaranya. Dalam perspektif kajian ilmiah, permusuhan mereka terhadap Islam disebabkan oleh kebodohan meteka terhdap hakikat Islam dan bahasa Arab. Oleh karenanya tidak dapat dikatakan bahwa permusuhan tersebut merupakan aspek manusiawi, melainkan disebabkan faktor subyektifitas yang biasanya mendorong manusia berbuat aniaya, sewenang-wenang dan tidak proporsional dengan tujuan memaksakan kehendak dan menunjukkan arogansi yang berlebihan. ${ }^{12}$

Berangkat dari pernyataan tersebut, Wizan meragukan obyektifitas dan itikad baik yang mendasari orientalisme. Ada kepentingan untuk mengontrol dan mendefinisikan Timut (baca: Islam) oleh kekuatan-kekuatan dominan, yaitu penguasa Barat. Subyektifitas Barat beroperasi secara halus dalam konstruksi tentang Islam. Dunia Islam kemudian dihadirkan sesuai dengan kacamata dan parameter yang digunakan Barat. Akhirnya, bukan hanya Islam yang irasional yang

${ }^{9}$ Olaf Schuman (1996), Persepsi Diri dan Persepsi Majemuk di Barat, dalam M. Natsir Tamara dan Peldi Taher (Editor), Agama dan Dialog antar-Peradaban, Jakarta: Paramadina, pp. 47-81.

${ }^{10}$ Hasan Hanafi (2003), Cakrawala Baru Peradaban Global: Revolusi Islam untuk Globalisme, Phuralisme, dan Egaliterisme Antar Peradaban, Yogyakarta: IRCiSOD, p. 71.

${ }^{11}$ Adnan M. Wizan (2003), Akar Gerakan Orientalisme; dari Perang Fisik Menuju Perang Pikir, Yogyakatta: Fajar Pustaka, p. 130.

${ }^{12}$ Ilid., p. 131. 
terepresentasikan, melainkan juga Islam yang tidak menghargai HAM, menyukai perang atau kekerasan, dst. Maka orientalisme dalam pandangan Wizan lebih metupakan ghozwul fikri ketimbang sebuah kajian ilmiah. Representasi dunia Islam di "panggung Barat" tidak bisa dijamin obyektifitasnya, lantaran motifasi yang menggetakkan dan melatarinya adalah pertarungan dan perebutan kekuasaan.

Analisis Wizan tidak terlepas dari dukungan, mainstream umat Islam menunjukkan ketidak-sukaan tethadap orientalisme. Bahkan dari luar dunia Islampun mengindikasikan hal serupa. Edward Said misalnya, seorang Palestina yang beragama Katolik, dalam karyanya yang sangat monumental berjudul Orientalism. memberikan kritik tajam kepada epistemologi orientalisme. Bagi Said, tidak ada orientalisme tanpa bias politik dan budaya. Ketika Timur ditekstualisasikan oleh Barat, maka saat itu ada kepentingan politik untuk menghadirkan inferioritas Timur (Islam) dan superioritas Barat. Dengan demikian, Barat tidak melihat dan menilai dunia Timur sebagaimana adanya (obyektif), melainkan sebagaimana kepentingannya. Tampaknya Said mengadopsi dan menerapkan teori formasi diskursif Foucault, karenanya Said menyimpulkan bahwa orientalisme tidak lebih merupakan ajang pertukaran berbagai jenis kekuasaan ${ }^{13}$. Said membedakan empat jenis kekuasaan yang berkontestasi di seputarnya, yakni kekuasaan politis, intelektual, budaya, dan moral. Kekuasaan politis dimaksudkan sebagai pembentukan kolonialisme dan imperialisme, sedangkan kekuasaan intelektual bermakna bahwa Barat hendak mendidik Timur, sebab Timur dinilai bodoh, tidak menguasai ilmu pengetahuan, menyukai kekerasan, irasional, mistis, dst. Kekuasaan budaya mengandung tujuan tidak jauh betbeda dengan yang kedua, sementara kekuasaan moral menentukan dan mengontrol Timur tentang yang baik dan yang buruk. Kesimpulannya, keempat jenis kekuasaan yang beroperasi di balik orientalisme bemuara pada legitimasi superioritas Batat terhadap Timur. Timur Barat panggung yang mementaskan drama dan kejadian, sementara Barat adalah penontonnya yang melihat dan menilai Timur dengan ukuran-ukuran peradaban Barat.

Sungguhpun Bryan S Turner melihat adanya kelemahan dalam buku Said tentang orientalisme, namun karya Said memberikan kontribusi signifikan dalam perkembangan kajian tentang orientalisme. Menurut Turner, salah satu sisi lemahnya adalah bahwa tidak memadai menyatukan beberapa tradisi orientalisme yang berbeda menjadi tradisi orientalis yang tunggal. ${ }^{14}$ Said memang sangat menguasai orientalisme Perancis dan Inggris, tetapi lemah tentang orientalisme Jerman. Namun tetlepas dati itu, karya Said memberikan legitimasi ilmiah bagi ketidaktelaan Timur dihadirkan oleh Barat dalam orientalisme.

Perbincangan mengenai orientalisme menimbulkan gugatan mendasar, apakah Barat berhak merepresentasikan kebudayaan Timur (baca: Islam), lalu bagaimana

${ }^{13}$ Edward Said, op. cit., p. 12 .

${ }^{14}$ Bryan S. Turner (2002), Orientalisme, Posmodernisme, dan Globalisme, Jakarta: Riota Cipta, p. 6. 
mengevaluasi validitas produksi tersebut, juga bagaimana memilah antara kebenaran suatu objek (objektifitas) dan kepalsuan (subjektifitas)? Kemunculan Orientalisme bertolak dari Eurosentrisme, yakni sikap yang secara tidak kritis menganggap Eropa (baca:Batat) superior ketimbang Timur.

Eutosentrisme menurut Yasraf Amir Piliang berpandangan bahwa Barat berhak dan memiliki otoritas untuk merepresentasikan serta menilai Timur. ${ }^{15}$ Epistemologi Barat menjelaskan bahwa "sang aku" yang berpikit adalah eksistensi mutlak. Dengan kata lain, Barat yang menggunakan standat-standar berpikir ilmiah berhak untuk menilai dan menghakimi kebudayaan lain. Subjektifitas Barat mengklaim berdiri di atas objektifitas dan standar metode ilmiah. Karena itu, Timur yang dihadirkan oleh Barat dianggap tidak teteduksi dan "tersudutkan".

Dalam konteks perbincangan orientalisme, terlihat ada dua subjek yang berhadapan, Barat dan Timur (baca:Islam). Di sini pihak Batat menjadi "sang aku" dan Timur sebagai "sang kamu". Dalam orientalisme "sang aku"secara aktif mendefinisikan dan menilai "sang kamu". Bahkan "sang kamu"sendiri mengenal dirinya melalui "sang kamu aku". Walhasil pusat pengontrol definisi dan pengukur baik dan buruk ada pada "sang aku", yakni Barat. Sejatinya, masing-masing secara aktif merepresentasikan dirinya kepada yang lain. Sehingga definisi diri tidak tereduksi oleh subjektifitas "yang lain".

\section{G. Pendidikan dan Kebudayaan dalam Memerangi Terorisme}

Sisi lemah dati kemajuan peradaban Batat adalah terkikisnya keatifan perenmial. Sebab, meyakini alam sebagai mesin raksasa yang bekerja secara mekanistik dan deterministik. Tuhan, dalàm paradigma Barat, telah tergeserkan dengan hukum alam yang bekerja secata matematis. Di sinilah materialisme berjaya, yang merayakan empirisme dan positivisme sebagai kebenatan tettinggi. Paradigma ini berakar kuat dari atsitek modernisme, Rene Descartes dan Newton, dan dipakai diseluruh disiplin keilmuan (Sosiologi, Biologi, Psikologi, dll). Atas dasar itu, Arnold Toynbee menyebutkan bahwa telah terjadi ketimpangan besar dalam peradaban Barat. Di satu sisi sains dan teknologi betkembang pesat, di sisi lain kearifan moral dan kemanusiaan tidak mengalami petkembangan ${ }^{16}$.

Peradaban Barat seakan menyiratkan bahwa kemajuan harus dilandasi dengan penolakan campur tangan Tuhan. Namun dampak negatif dari pandangan tersebut jelas terasa, tersingkinya "kearifan perennial". Kebijakan pemetintah Barat seakan menafikan moralitas, semuanya bermuara pada kepentingan politik kelompok. Inilah salah satu kritik Hans Kung dalam bukunya $A$ Global Etbics for Global politics and

${ }^{15}$ Yasraf Amir Piliang (1999), Sebuah Dunia jang Dilipat: Realitas Kebudajaan Menjelang Milenium Ketiga dan Matinya Posmodernisme, Bandung: Mizan, p. 177.

${ }^{16}$ Arnold Toynbee (1976), Choose Life: A Dialogue, ttp, p. vi. 
Economics ${ }^{\mathrm{t}}$. Diskriminasi terhadap Palestina didorong oleh adanya kepentingan politik pragmatis terhadap Israel. Nilai-nilai humanis tergeserkan oleh kepentingan yang lebih sempit, yaitu kekuasaan dan kekayaan.

Rasionalitas modern Cartesian-Newtonian juga mengarah pada "logika oposisi Biner", dimana tercipta pasangan yang bias seperti; subyek-obyek, Barat-Timur, akal-intuisi, materi-immateri, atas-bawah, laki-perempuan, dst. Yang disebut di awal lebih sempurna dan mulia daripada yang terakhir. Paradigma tersebut seakan menyiratkan bahwa Barat lebih mulia ketimbang Timur (baca: Islam). Seperti dikatakan oleh Richatd Rorty bahwa Barat mengidap Eurosentrisme, yaitu kebanggaan sebagai tas Etopa. Meski pendapat ini tidak bisa kita gunakan secara tepat kepada Barat dalam pengertian Amerika - sebab Amerika bukan bagian dari Eropa - namun setidaknya paradigma Cartesian mendorong lahirnya kebanggaan sebagai ras yang lebih unggul. ${ }^{18}$

Sementara itu, sebagian besar umat Islam sendiri masih berlandas pada teologi. eksklusif, yang meyakini bahwa kebenaran hanya milik Islam dan di luar Islam adalah sesat. Ini tentu juga memunculkan "arogansi teologis", sehingga relasi muslim dan non-muslim jadi terganggu. Bahkan eksklusifisme semacam ini akan mendorong untuk melakukan kekerasan. Logikanya akan membenarkan untuk menggunakan kèkerasan demi tegaknya kebenaran.

Mereka merujuk pada ajaran Islam hasil konstruksi "nalar klasik", yang memandang non-Muslim sebagai watga negara sekunder, yang dibebani kewajiban untuk membayar upeti kepada pemerintahan Islam. Bahkan memandang non-Muslim sebagai "kafir", suatu label yang memiliki beban pejoratif. Sungguh sebuah diskriminasi yang dilatatbelakangi perbedaan teologi, seakan ada "arogansi teologis". Dalam konteks tersebut "nalar klasik" membolehkan untuk melakukan teror terhadap "kafir" (Barat). Argumentasi Amrozi dkk dalam tragedi bom Bali jelas menyiratkan "arogansi teologis". Atas nama Tuhan mengoyak harkat kemanusian. Atas nama kebenaran menebar teror terhadap masyarakat Barat yang tidak berdosa. Jadi dengan patadigma semacam ini bagaimana mungkin bisa tercipta sebuah tatanan peradaban global yang saling memahami dan menghargai? Diperlukan sebuah "rekonstruksi peradaban". Rekonstruksi dimaksudkan agar masing-masing dapat meninjau ulang pandangan yang mendasari peradabannya. Sebagaimana telah dijelaskan di awal, peradaban Barat memiliki akar yang kuat dalam paradigma Cartesian-Newtonian. Sẹbenarnya beberapa ilmuwan Barat sendiri telah mulai melakukan kritik dan rekonstruksi, agar Barat lebih memiliki "kearifan peteninial". Getakan posmodernisme yang diwakili sayap rekonstruktif semacam Paul Ricouer, Gadamer, Fritchof Chapra,

${ }^{17}$ Hans Kung (2002), Etika Ekonomi Politik Globali Mencari Visi Barw bagi Kelangswngan Agama di AbadXXI, Yogyakarta: Qalam, p. 75.

${ }^{18}$ Ibid, p. 77 . 
Gary Zukav, dIl misalnya, telah banyak memberikan kontribusi bagi perbaikan tersebut. ${ }^{19}$ Sayangnya, pandangan ini belum dihayati secara mendalam oleh para pengambil kebijakan di Barat (baca: Amerika). Jadi tugas awal dalam membangan cakrawala baru peradaban global adalah merubah paradigma lama dalam benak mereka, dan itu adalah tugas cendekiawan Barat.

Sedangkan untuk Islam kita perlu melakukan "kritik nalat Islam" maksudnya sebagai dekonstruksi atas "nalar klasik", yakni dekonstruksi tethadap epistemologi yang digunakan dalam mengkonstruksi ajatan Islam. Dalam pemikitan Islam, kritik nalar diperkenalkan oleh beberapa pemikir Islam terkemuka, seperti Mohammad Abed Al-Jabiri, Mohammed Arkoun, Nashr Hamid Abu Zayd, Abdullahi Ahmed An-Naim, dll. Mereka secara khusus melakukan penelaahan pada syari'ah Islam, baik pemikiran Teologi, Fiqih, ataupun Filsafat.

Dalam pandangan Abdullahi Ahmed An-Naim misalnya, "nalar klasik" tejebak pada teks kitab suci yang ditutunkan pada periode Madinah. Padahal pada periode ini ada tuntutan tealitas yang mengkondisikan syari'ah Islam menjadi eksklusif dan bersifat lokal-partikular. Relasi muslim dan non-muslim, gender, dst berada dalam konteks ruang dan waktu yang partikular. Sehingga mengharuskan syari'ah dikemas dengan budaya lokal. Seperti dapat dicermati dalam kitab suci, teks yang turun diperiode ini seakan membedakan muslim dan non-muslim. Penggunaan tetm kafir dzimmi (kafir yang dilindungi) memposisikan meteka sebagai warga negara kelas dua, berbeda dengan muslim. Maka An-Na'im menawatkan "evolusi syari'ah", yakni beranjak meninggalkan teks periode Madinah menuju teks periode Mekkah" ${ }^{20}$. Di periode ini ajatan Islam betbicata tentang sesuatu yang universal, mengenai relasi gender misalnya, laki-laki dan perempuan diciptakan setara, kemudian seruan kebaikan ditujukan kepada seluruh manusia, bukan banya muslim. Jadi jelas, "volusi syari'ah" adalah sebuah tawaran tentang "nalar Islam modern" yang memandang kesetataan.

Sementara Al-Jabiri mencermati bahwa konstruksi ajaran Islam terkait dengan kekuasaan. Ia kerap digunakan untuk menopang kekuasaan. Oleh katena itulah "nalar klasik" bermain di antara pertarungan kekuasaan. Maka menurut Al-Jabiri membongkat tradisi klasik untuk membuat tradisi baru yang sejalan dengan modernitas adalah sebuah keniscayaan. Merubah paradigma lama dalam umat Islam tentu merupakan tugas internal cendekiawan Islam. Dengan begitu, harapan terciptanya peradaban global yang hatmonis bisa diwujudkan.

${ }^{19}$ I. Bambang Sugiharto (1996), Post-Modernisme: Tantangan bagi Filsafat, Yogyakarta: Kanisius, Pp. 15-21.

${ }^{20}$ Abdullah Ahmed An-Naim (2001), Dekonstruksi Syariab: Wacana Kebebasan Sipil, Hak Asasi Manusia, dan Hubungan Internasional dalam Islam, Yogyakarta: LkiS, pp. 307-347. 


\section{H. Penutup.}

Dari uraian di atas, ada beberapa poin yang dapat diambil yaitu;

Pertama, upaya menentang terorisme tak ubahnya berperang melawan kelompok getilyawan dengan lawan dan strategi yang tidak jelas. Aktivitas yang dilakukan dari keduanya mengarah pada hal yang sama, yaitu pencapaian tujuan politik. Kata tetoris dan terotisme kemudian hadir tidak lebih sebagai simplikasi agat terdapat objek yang diperangi dalam menentang kejahatan terhadap kemanusiaan.

Kedua, tetot adalah kekerasan yang muncul dari adanya konflik. Konflik yang seting terjadi di muka bumi baik yang vertikal maupun horizontal pada dasarnya betakat pada dua aspek. Aspek pertama adalah lingkungan, yaitu bagaimana lingkungan yang tidak kondusif membuat manusia secara emosional tertekan sehingga membuatnya frustrasi pada keadaan. Apabila hal tersebut didiamkan, akan muncul impuls yang positif terhadap pemberontakan diri berupa tindakan kekerasan, tetmasuk di dalamnya tindakan terorisme. Aspek kedua adalah persoalan dalam diri manusia sendiri. Para psikoanalisis menyatakan bahwa setiap manusia memiliki insting yang dinamakan insting kematian. Artinya, setiap individu memiliki jiwa untuk melakukan tindakan kekerasan (teror) tethadap orang lain.

Ketiga, agama tidak hanya memainkan peranan dalam menciptakan integrasi dan harmoni sosial, tetapi ia juga bisa menjadi faktor konflik dalam masyarakat yang mengarah pada tindakan terorisme.

Keempat, berakhirnya perang dingin telah membawa konsekuensi pada perubahan ancaman atas keamanan internasional. Berbeda dengan periode perang dingin (militer/hard issues), pada periode pascaperang dingin saat ini, ancaman keamanan internasional bersumber dari masalah-masalah nonmiliter. 


\section{DAFTAR PUSTAKA}

Abdullah Ahmed An Naim (2001), Dekonstruksi Syariab: Wacana Kebebasan Sipil, Hak Asasi Manusia, dan Hubungan Internasional dalam Islam, Yogyakarta: LkiS. Adjie S. (2005), Aksi Terorisme Dunia, Jakarta: Pustaka Sinar Harapan.

Adnan M Wizan (2003), Akar Gerakan Orientalisme; dari Perang Fisik Menuju Perang

Pikir, Yogyakarta: Fajar Pustaka.

Ali Maschan Moesa (2005), “Terorisme Sebagai Soft Issues (Non-Militer") Jawapos, Sabtu

26 November 2005.

Edwat Said (1978), Orientalism, Penguin.

Foulcault, Michael (1972), The Arcbaeology of Knowledge and The Discourse on Language,

New York: Pantheon Books.

Hasan Hanafi (2003), Cakrawala Baru Peradaban Global: Revolusi Islam untuk

Globalisme, Pluralisme, dan Egaliterisme antar Peradaban, Yogyakarta: IRCiSOD.

http:/ /islamlib.com/id/index.php?page $=$ article\&id $=160$.

http://www.harunyahya.com/indo/buku/terorisme001.htm.

http://www.merc.org/mc/ina/rubrik/rb_sbn_02.htm.

http:://buletinlitbang.dephan.go.id/index.asp?vnomot=8\&mnototisi=2.

Huntington, Samuel P. (1998), The Clash of Civilizations and the Remaking of World

Order, London: Touchstone.

I Bambang Sugiharto (1996), Post-Modernisme: Tantangan Bagi Filsafat, Yogyakarta: Kanisius.

Jamhari dan Jajang Jahroni (2004), Gerakan Salafi Radikal di Indonesia, Jakarta: UIN Press.

Kung; Hans (2002), Etika Ekonomi Politik Global: Mencari Visi Baru bagi Kelangsungan Agama di Abad XXI, Yogyakarta: Qalam.

Leela Gandhi (2001), Teori Poskolonial: Upaja Meruntubkan Hegemoni Barat, Yogyakarta: Qalam.

Loudewijk F. Paulus (2000), Terorisme, Buletin Balitbang Dephan, htm.www.dephan.com.

Sarbini Abdul Murad (tt), Terorisme dan Keadilan Global (Sebuab Catatan Kilas Balik). Schuman, Olaf (1996), "Persepsi Diri dan Persepsi Majemuk di Barat" dalam M. Natsir Tamara dan Peldi Taher (Editor), Agama dan Dialog antar-Peradaban, Jakarta: Paramadina.

Sluka, Jeffrey A. (Ed) Dead Squad: The Anthropology of State Terror, Philadelpia: University of Pensylvania Press.

Spencer, Robett (2003), Islam Ditelanjangi: Pertanyaan-pertanyaan Subversif Seputar

Doktrin dan Tradisi Kaum Muslim, Jakarta: Paramadina.

Toynbee, Anold (1976), Choose Life: A Dialogue, Tanpa tempat 
118 Millah Vol. VI, No. 1, Agustus 2006

Turner, Bryan S (2002), Orientalisme, Posmodernisme, dan Globalisme, Jakarta: Riora Cipta.

Yasraf Amir Piliang (1999), Sebuab Dunia yang Dilipat: Realitas Kebudayaan Menjelang Milinium Ketiga dan Matinya Posmodernisme, Bandung: Mizan. 